\title{
A MULTIPLE LOGISTIC REGRESSION OF FACTORS AFFECTING THE DEMAND OF MODERN CONTRACEPTIVES IN MALINAU, NORTH KALIMANTAN
}

\author{
Yuliana Agus'), Eti Poncorini Pamungkasari2), RB. Soemanto3) \\ ${ }^{1)}$ Masters Program in Public Health, Universitas Sebelas Maret \\ 2)Faculty of Medicine, Universitas Sebelas Maret \\ 3)Faculty of Social and Political Sciences, Universitas Sebelas Maret
}

\begin{abstract}
Background: Family planning is a key to reduce unintended pregnancies. In the developing country, there is more heterogeneity in perspectives on family planning and contraception, depending on the history of a given country, its culture and religions, and where it is demographically, economically, and epidemiologically. This study aimed to determine factors affecting the demand of modern contraceptives in Malinau, North Kalimantan, Indonesia.

Subjects and Method: A cross sectional study was conducted at 4 sub-districts in Malinau, North Kalimantan, Indonesia, from December 2018 to January 2019. A sample of 200 mothers was selected by fixed disease sampling. The dependent variable was demand of contraceptive. The independent variables were age, parity, residence, education, income, perception, intention, attitude, and subjective norm. The data were collected by questionnaire and analyzed by a multiple logistic regression.

Results: The demand of modern contraceptives among women was affected by parity $(\mathrm{b}=3.03 ; 95 \% \mathrm{CI}=1.23$ to $4.83 ; \mathrm{p}<0.001)$, intention $(\mathrm{b}=4.84 ; 95 \% \mathrm{CI}=2.85$ to 6.82 ; $\mathrm{p}<0.001)$, attitude $(\mathrm{b}=3.92 ; 95 \% \mathrm{CI}=1.42$ to $6.42 ; \mathrm{p}=0.002)$, and family income $(\mathrm{b}=$ 4.57; $95 \% \mathrm{CI}=2.66$ to $6.47 ; \mathrm{p}<0.001)$.

Conclusion: The demand of modern contraceptives among women is affected by parity, intention, attitude, and family income.
\end{abstract}

Keywords: modern contraceptives, demand, intention, attitude

\section{Correspondence :}

Yuliana Agus. Masters Program in Public Health, Universitas Sebelas Maret, Jl. Ir. Sutami 36A, Surakarta 57126, Central Java. Email: yulianaaguso7@gmail.com. Mobile: 085343928921

The $6^{\text {th }}$ International Conference on Public Health

Best Western Premier Hotel, Solo, Indonesia, October 23-24, 2019 | 154

https://doi.org/10.26911/the6thicph.03.12 